\title{
Towards Sustainable Oil Palm Plantation Management: Effects of Plantation Age and Soil Parent Material
}

\author{
Georges Kogge Kome*, Fritz Oben Tabi \\ Department of Soil Science, Faculty of Agronomy and Agricultural Sciences, University of Dschang, Dschang, Republic of \\ Cameroon \\ Email: *komegeo@yahoo.fr
}

How to cite this paper: Kome, G.K. and Tabi, F.O. (2020) Towards Sustainable Oil Palm Plantation Management: Effects of Plantation Age and Soil Parent Material. Agricultural Sciences, 11, 54-70. https://doi.org/10.4236/as.2020.111004

Received: October 9, 2019

Accepted: January 3, 2020

Published: January 6, 2020

Copyright () 2020 by author(s) and Scientific Research Publishing Inc. This work is licensed under the Creative Commons Attribution International License (CC BY 4.0).

http://creativecommons.org/licenses/by/4.0/

\section{(c) (i) Open Access}

\begin{abstract}
This study was conducted to generate information required to guide plantation management in relation to replanting on soils derived from different parent materials. Six oil palm estates in coastal lowlands of southwest Cameroon were considered. Oil palm yield data (in $\mathrm{t}_{\mathrm{h}} \mathrm{a}^{-1}$ of fresh fruit bunch, FFB) and corresponding age of palms (in years after planting, YAP) were obtained for the various estates. In all the estates, average yields were $<10 \mathrm{t} \cdot \mathrm{FFB} \cdot \mathrm{ha}^{-1}$ and highly variable. Plantation age, solely, explained between $20 \%-58 \%$ of the variation in yield. The highest average yields $\left(11.5 \mathrm{t} \cdot \mathrm{FFB} \cdot \mathrm{ha}^{-1}\right)$ were obtained in plantations aged between 9 and 18 YAP and the lowest (4.66 t.FFB $\cdot h^{-1}$ ) were obtained in old plantations ( $>23$ YAP). Plantations located on volcanic parent materials generally had higher yields compared to those established on sedimentary parent materials. In order to intensify production and increase yields while conserving the environment, one important measure to consider is the replacement of aged palms, and the recommended optimal replanting age in coastal plains of southwest Cameroon should be at most 23 YAP. Estimated mean yields, if aged palms are replanted on time, can increase by $43 \%$ - 65\%. Additionally, site-specific nutrient management options should be considered in plantation intensification programs.
\end{abstract}

\section{Keywords}

Elaeis guineensis, Yield Variation, Coastal Plain Soils, Intensification, Oil Palm Replanting, Cameroon

\section{Introduction}

African oil palm (Elaeis guineensis Jacq.) is a perennial oil-producing plant, in- 
digenous to West Africa and happens to be the most productive vegetable oil crop. Annual global production is more than 35 million metric tons of palm oil with Malaysia and Indonesia contributing $>80 \%$ of global production [1]. During the past decade, the total area under production was about 14 million hectares [2]. Between 2000 and 2012, the global oil palm planting area increased from 10 to 17 million hectares [3], following the conversion of most tropical forests, pastures and peatlands. Consequently, global oil palm expansion has been a major driver of deforestation, severe loss of biodiversity [4] [5] and greenhouse gas emissions [6]. Additionally, ecosystem functions (such as soil erosion prevention, water regulation and water supply, climate regulation and mitigation of extreme events, etc.) are greatly reduced following the conversion of natural forests to oil palm plantations [7]. The rapid expansion of oil palm planting areas and the high quantities of oil palm production have been due to increased demand of palm oil for food, industrial transformations, and biofuel production [8], and also because it is the least expensive of all vegetable oils. The oil palm is the most productive oil crop in terms of oil yield per hectare and resource use efficiency due to its high efficiency at transforming solar energy into vegetable oil [9]. The average yield of palm oil is approximately $4.2 \mathrm{t} \cdot \mathrm{ha}^{-1} \cdot \mathrm{yr}^{-1}$, with yields exceeding $6.0 \mathrm{t} \cdot \mathrm{ha}^{-1} \cdot \mathrm{yr}^{-1}$ in the best-managed plantations. Oil palm yields are far greater than those of vegetable oils such as rapeseed and soybean that produce only 1.2 and $0.4 \mathrm{t} \cdot \mathrm{ha}^{-1} \cdot \mathrm{yr}^{-1}$, respectively [10]. However, optimal oil palm yields are hardly achieved in both smallholder farms and agro-industrial estates due to several factors that cause yield gaps. Although Cameroon has very favourable environmental conditions (climate and soil) for achieving optimum oil palm production, actual yields are far below the potential yields. For example, as of 2012, Cameroon recorded a total production of 230,000 $\mathrm{t}$ of crude palm oil (CPO) from approximately 190,000 ha exploited by both agro-industries and small/medium holdings [11], giving approximately $2.6 \mathrm{t} \cdot \mathrm{CPO} \cdot \mathrm{ha}^{-1}$. Considering smallholders only, oil palm yields hardly exceed $1.0 \mathrm{t} \mathrm{CPO} \cdot \mathrm{ha}^{-1} \cdot \mathrm{yr}^{-1}$. It has also been reported that agro-industries in Cameroon such as the Cameroon Development Corporation (CDC) and PAMOL plantation Plc hardly produce 2 $\mathrm{t} \cdot \mathrm{CPO} \cdot \mathrm{ha}^{-1} \cdot \mathrm{yr}^{-1}$ meanwhile smallholders in Indonesia reach much better yields of 3.0 to $3.5 \mathrm{t} \cdot \mathrm{CPO} \cdot \mathrm{ha}^{-1} \cdot \mathrm{yr}^{-1}$ [12]. The low yields in oil palm have rendered Cameroon a net importer of palm oil due to the high national demand, mostly for industrial transformation (especially in soap production). From 1999 to 2004, the import of vegetable oils increased by $366 \%$ with palm oil accounting for $55 \%$ of the imports [13]. Again, imported CPO in Cameroon increased from 16,000 tons in 2016 to 95,000 tons in 2017 [14].

Faced with the challenge of achieving optimum oil palm yields, it is imperative to identify factors causing the yield gaps in order to generate information required to guide on appropriate management strategies that will increase oil palm yields and sustain production. According to Ruiz et al. [15], a gap in crop yield is defined as the difference between yields obtained by producers in their 
own particular conditions and the potential yield. Potential yield refers to what should be obtained if there were no limiting factors regarding crop management [16]. Different factors create yield gaps in oil palm, including climate constraints, soil constraints, planting materials and their characteristics, and adoption of different technologies [15]. An extensive review of factors contributing to oil palm yield gaps has been done by Woittiez et al. [17], wherein four production levels have been distinguished; the potential, water-limited, nutrient-limited, and the actual yield. According to Woittiez et al. [17], closing these yield gaps could increase global production by $15-20 \mathrm{Mt} \cdot \mathrm{oil}^{-\mathrm{yr}^{-1}}$, which would limit the drive for further area expansion at a global scale, and hence limit the negative consequences of deforestation.

In Cameroon, many factors contribute to declining oil palm yields, including climatic variations [18] [19] [20], inappropriate plantation management, limited inputs (fertilizers), labour shortage, pests and diseases [11], and the continued exploitation of old plantations ( $>25$ years) [21]. While most of these studies have focused on the influence of climatic factors on oil palm yields, little or no studies are available for explaining how plantation age influences oil palm yields in $\mathrm{Ca}$ meroon. In Malaysia and Indonesia, such investigations have been carried out extensively and the findings have been very useful in identifying the optimal age for oil palm replanting. With regards to oil palm age and productivity of fresh fruit bunch (FFB), Fairhurst and Griffiths [22] have identified four yield phases; 1) the immature or "yield building" phase, 2 - 3 years after planting (YAP), before harvestable production begins and when canopy is not yet closed; 2) the young mature phase or "steep ascent yield phase", 4 - 7 YAP, when leaf area and yield increase linearly; 3 ) the mature or "plateau yield phase", 8 - 14 YAP, when yield and leaf area are stable; and 4) a phase of yield decline, 15 - 25 YAP, when leaf production rate and bunch number decreases. Under favourable conditions, the young mature phase ( 4 - 7 YAP) can produce $10-15 \mathrm{t} \cdot \mathrm{FFB} \cdot \mathrm{ha}^{-1}$, while typical commercial yields can reach 25 - $30 \mathrm{t} \cdot \mathrm{FFB} \cdot \mathrm{ha}^{-1}$ in well-managed plantations [17]. According to Butler et al. [2], average production of FFB yield in Sumatra ranges from $17 \mathrm{t} \cdot \mathrm{ha}^{-1}$ (low-yield scenario) to $20.5 \mathrm{t} \cdot \mathrm{ha}^{-1}$ (high-yield scenario), based on estimates from average FFB yields in Indonesia and Malaysia. Additionally, FFB yields increase from $5.9 \mathrm{t} \cdot \mathrm{ha}^{-1}$ in the third year of planting to $21.9 \mathrm{t} \cdot \mathrm{ha}^{-1}$ in the ninth year, before decreasing to about $12.1 \mathrm{t} \cdot \mathrm{ha}^{-1}$ in the 25 th year, under the low yield scenario [2]. Under the high-yield scenario, FFB yields increase from 7.1 $\mathrm{t} \cdot \mathrm{ha}^{-1}$ in the third year of planting when palm trees reach maturity to $26.4 \mathrm{t} \cdot \mathrm{ha}^{-1}$ in the ninth year, before decreasing to $14.6 \mathrm{t} \cdot \mathrm{ha}^{-1}$ in the 25 th year. Based on the aforementioned yield phases, optimal replanting age for oil palm can be established in order to maximize yields per unit area. In general, one life cycle of oil palm is 25 years [23] [24], after which the harvest becomes too complex and expensive as soon as the palms are too high-hence palms are felled and another crop cycle is initiated [23]. During the life cycle, potential yield varies between 18 - 30 thha $^{-1}$ of FFB under suitable agro-climatic conditions [25]. From an eco- 
nomic point of view, Faris [26] reported that the optimum age of replanting corresponds to the time when the marginal net revenue in year of the present stand is equal to or exceeds the amortized value of net revenue in year of the second stand. Thus, the optimum replanting age depends on the price of FFB, cost to establish and maintain new palms, technology that changes the yield profile, and the discount rates adopted.

Although the useful life of a palm tree with respect to fresh fruit bunch (FFB) production has been established by different authors, a common practice in most oil palm plantations and small farm holdings in Cameroon is the non respect of age limit required for renewing aged plantations. This practice is more pronounced on soils with high fertility status. As a result, FFB yields are low and continue to decline even on volcanic soils which are generally fertile. Increase in oil palm production is now synonymous with the opening of new farmlands despite numerous environmental consequences associated with it. Additionally, there is an existing myth that very old palms can be productive and profitable on fertile soils. The objective of this study was to generate information required to guide plantation management in relation to replanting on soils derived from different parent materials. More specifically, the study aimed to identify the age range of plantations, to establish age-FFB yield relationships and to ascertain the age limit of a palm tree for optimum productivity.

\section{Materials and Methods}

\subsection{Location and Description of Study Area}

The study was carried out in the lowland plains of Southwest region of Cameroon, a region constituting the major oil palm growing areas of the country. Considering climatic and soil suitability, the area is in general suitable for oil palm cultivation and growth [27] [28] and can thus be considered a representative sample of oil palm cultivation in the oil palm belt of Cameroon. The sampling areas consisted of oil palm plantations of the Cameroon Development Corporation (CDC), situated within lowland plains surrounding the Cameroon Mountain (Figure 1). Most of the major oil palm plantations of Southwest Cameroon are a threat to important forest and wildlife reserves of Central Africa such as the Bakossi mountains national park, the Rumpi Hills wildlife reserve, the Korup National park, the Banyang-Mbo wildlife sanctuary and the Nta-Ali forest reserve, this as a result of their continued expansion. Oil palm plantations established in some parts of these protected areas have resulted in great loss in biodiversity and disturbance of the livelihood of the local population. Recently, some giant oil palm expansion projects have been launched in the area, and if allowed to be carried out, will lead to severe loss of forest and biodiversity. According to the Koppen climate classification, the area has the equatorial climate type (Am), precisely the Cameroon type, which is quite hot and humid, characterized by the existence of two distinct seasons-one wet (rainy) season (March 
to October) and a comparatively short dry season (November to February). The dominant type is the mountain Cameroon type where rainfall is very high with more than $2000 \mathrm{~mm}$ annual rainfall. Rainfall varies greatly across the different sites due to the influence of the Cameroon Mountain, the Atlantic Ocean and the north-easterly winds from the Sahara, commonly known as the Harmattan [29].

Mean annual temperature is slightly different across the various sites, ranging between $25^{\circ} \mathrm{C}$ and $26^{\circ} \mathrm{C}$ (Table 1). Relative humidity is high, generally exceeding $80 \%$. The reference soil groups (IUSS/FAO/ISRIC WRB) in the study area consist of Andosols, Leptosols, Haplic and Rhodic Nitisols, and Ferralsols [30]. These soil groups fall under the soil orders Andisols, Entisols, Alfisols, Ultisols and Oxisols, respectively, following the U.S. Soil Taxonomy. Soil parent material within the area is mainly sedimentary and volcanic in nature and is highly varied, including basaltic lavas, recent alluvial deposits, old and recent volcanic ash deposits.

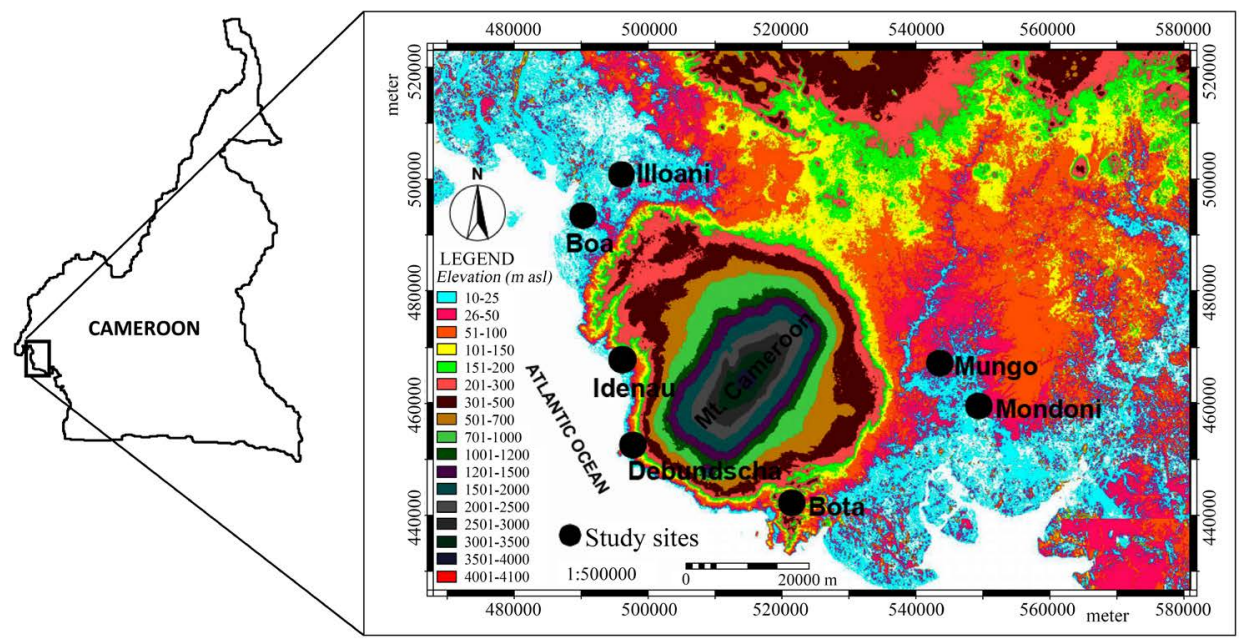

Figure 1. Topographic map showing location of the study sites in Southwest Cameroon.

Table 1. Biophysical characteristics of study sites.

\begin{tabular}{|c|c|c|c|c|c|c|}
\hline \multirow{2}{*}{$\begin{array}{l}\text { Biophysical } \\
\text { characteristics }\end{array}$} & \multicolumn{6}{|c|}{ Oil palm estates } \\
\hline & Mondoni & Debundscha & Bota & Mungo & Idenau & Illoani-Boa \\
\hline Rainfall (mm) & 3021 & 9099 & 3517 & 2085 & 8332 & 3470 \\
\hline Min. Temp. $\left({ }^{\circ} \mathrm{C}\right)$ & 22.2 & 22.4 & 21.6 & 22.8 & 21.5 & 22.0 \\
\hline Max. Temp. $\left({ }^{\circ} \mathrm{C}\right)$ & 29.8 & 28.8 & 30.2 & 29.4 & 29.1 & 30.1 \\
\hline Mean Temp. $\left({ }^{\circ} \mathrm{C}\right)$ & 26 & 25.6 & 25.3 & 26.1 & 25.6 & 26.1 \\
\hline $\begin{array}{c}\text { Dominant } \\
\text { parent material }\end{array}$ & $\begin{array}{l}\text { Superficial } \\
\text { alluvial } \\
\text { sediments }\end{array}$ & $\begin{array}{l}\text { Tertiary aphyric } \\
\text { basalt with } \\
\text { trachyte intrusions }\end{array}$ & $\begin{array}{l}\text { Tertiary aphyric } \\
\text { basalt with } \\
\text { trachyte intrusions }\end{array}$ & $\begin{array}{l}\text { Mio-pliocene } \\
\text { coastal } \\
\text { sediments }\end{array}$ & $\begin{array}{c}\text { Basalt }+ \text { Quaternary } \\
\text { volcanic ash } \\
\text { and lapilli }\end{array}$ & $\begin{array}{l}\text { Superficial } \\
\text { alluvial } \\
\text { sediments }\end{array}$ \\
\hline $\begin{array}{c}\text { Dominant soil } \\
\text { orders (US Taxonomy) }\end{array}$ & Inceptisols & Andisols, Inceptisols & $\begin{array}{c}\text { Entisols, Inceptisols, } \\
\text { Ultisols }\end{array}$ & $\begin{array}{l}\text { Andisols, } \\
\text { Inceptisols }\end{array}$ & $\begin{array}{l}\text { Entisols, } \\
\text { Inceptisols }\end{array}$ & $\begin{array}{l}\text { Entisols, } \\
\text { Ultisols }\end{array}$ \\
\hline
\end{tabular}




\subsection{Source of Data and Statistical Analysis}

Due to lack of reliability of smallholder oil palm yield data, yield data (measured in $\mathrm{t} \cdot \mathrm{ha}^{-1}$ of FFB) and corresponding age of plantations (in years after planting, YAP) was obtained for different oil palm estates of the Cameroon Development Corporation (CDC) in the Southwest region of Cameroon. The estates were Mondoni, Debundscha, Bota, Mungo, Idenau and Illoani-Boa. Yield data was mostly recorded on a monthly basis. The data included yields recorded from 2005 to 2017.

The data was subjected to descriptive analysis in order to appreciate mean values, range in yields, variation in yields, etc. For a particular study site, simple and polynomial regression analysis was performed to appreciate the relationship existing between yield and plantation age. Correlation analysis was performed to measure the strength of the relationship existing between yield and age. In order to further appreciate the relationship existing between yield and age, yield data was grouped according to different age classes as defined by [25]. These classes included: young trees (3 - 8 YAP), prime (9 - 18 YAP), ageing (19 - 23 YAP) and old ( $>23$ YAP). Variability in oil palm yield within each of the classes was evaluated using the coefficient of variation (CV). Various oil palm plantations were grouped according to the dominant soil parent materials (mainly sedimentary and volcanic) in order to investigate the influence of parent material on oil palm yield.

\subsection{Estimation of Oil Palm Yield Gaps}

Yield gaps in the various sites were quantified as the ratio of real or actual yield obtained with respect to potential yield, expressed in percentage (Equation (1)) [15].

$$
\text { Yield gap }(\%)=\frac{\text { Actual }(\text { real }) \text { yield }\left(\text { in } t \text { of FFB } \cdot \mathrm{ha}^{-1}\right)}{\text { Potential yield }\left(\text { in } t \text { of FFB } \cdot \mathrm{ha}^{-1}\right)} \times 100
$$

Potential yield in southwest Cameroon was obtained from Feintrenie et al. [31]. According to the latter, taking into consideration climatic, topographic, pedological and management (conventional cropping practices and required fertilization, etc.) conditions of the entire study area (Southwest region of Cameroon), potential yields are estimated between 12 (minimum) and 25 (maximum) $\mathrm{t} \cdot \mathrm{ha}^{-1} \cdot \mathrm{yr}^{-1}$. Rating of oil palm yields in southwest Cameroon was established as follows: Low $\left(<12 \mathrm{t} \cdot \mathrm{ha}^{-1}\right)$, Intermediate $\left(12-25 \mathrm{t} \cdot \mathrm{ha}^{-1}\right)$ and High $\left(>25 \mathrm{t} \cdot \mathrm{ha}^{-1}\right)$.

\section{Results}

\subsection{Relationship between Oil Palm Yield and Plantation Age}

Descriptive statistics of oil palm yield data and age are shown in Table 2. From 2005-2017, oil palms aged between 3 and 59 years were harvested from different plantations across the study area. In general, the actual yields are very low, ranging from 0 to $21 \mathrm{t} \cdot \mathrm{FFB} \cdot \mathrm{ha}^{-1}\left(\right.$ mean $\left.=7.70 \pm 0.23 \mathrm{t} \cdot \mathrm{FFB} \cdot \mathrm{ha}^{-1}\right)$ across all sites 
with a standard deviation of $4.58 \mathrm{t} \cdot \mathrm{FFB} \cdot \mathrm{ha}^{-1}$. Among the various sites, the oldest oil palm plantations are located in Bota (having plantations of up to 59 YAP), Mungo (up to 48 YAP) and Mondoni (up to 45 YAP). It is observed that oil palm yields show very great variation $(\mathrm{CV}>35 \%)$. From the yield data, it appears that the highest mean yields are obtained from estates with ages $<38$ YAP. Results of correlation analysis showed that in all sites, there was a significant correlation between FFB yield and age (Table 3 ). There was a significant negative correlation between tree age and yield in Mondoni, Bota, Mungo and Idenau $(\mathrm{p}<0.05)$, while the relationship was positive in Debundscha $(\mathrm{p}<0.01)$ and Illoani-Boa $(\mathrm{p}<0.05)$ estates.

The positive relationships observed in Debundscha and Illoani-Boa can be explained by the fact that the two sites have exploitable plantations with a maximum age of $34 \mathrm{YAP}$ and $32 \mathrm{YAP}$, respectively. Additionally, most of the yields obtained in these two sites increase gradually with age up to about 20 YAP, after which yields drop slightly (varying between 5 and $10 \mathrm{t} \cdot \mathrm{ha}^{-1}$ ) (Figure 2). In the other sites (Mondoni, Bota, Mungo and Idenau), yield increases gradually with age up to about $20 \mathrm{YAP}$, and then drops sharply afterwards $\left(<7 \mathrm{t} \cdot \mathrm{ha}^{-1}\right)$.

Table 2. Descriptive statistics of oil palm yield data $\left(\mathrm{t} \cdot \mathrm{ha}^{-1}\right)$ and plantation age (YAP).

\begin{tabular}{|c|c|c|c|c|c|c|c|c|}
\hline Estates & Variables & Minimum & Maximum & Mean \pm SE & Std. Dev & $\mathrm{CV}(\%)$ & Skewness \pm SE & Kurtosis $\pm \mathrm{SE}$ \\
\hline \multirow{2}{*}{$\begin{array}{l}\text { Mondoni } \\
(\mathrm{n}=106)\end{array}$} & Plantation age (YAP) & 3 & 45 & $19.19 \pm 1.42$ & 14.63 & 76.23 & $0.68 \pm 0.24$ & $-1.26 \pm 0.47$ \\
\hline & FFB Yield $\left(\mathrm{t} \cdot \mathrm{ha}^{-1}\right)$ & 1.00 & 21.20 & $7.60 \pm 0.41$ & 4.21 & 55.39 & $0.63 \pm 0.24$ & $0.08 \pm 0.47$ \\
\hline \multirow{2}{*}{$\begin{array}{c}\text { Debundscha } \\
(\mathrm{n}=106)\end{array}$} & Plantation age (YAP) & 1 & 34 & $11.61 \pm 0.73$ & 7.55 & 65.03 & $1.12 \pm 0.24$ & $1.12 \pm 0.47$ \\
\hline & FFB Yield $\left(\mathrm{t} \cdot h \mathrm{a}^{-1}\right)$ & 0.00 & 20.00 & $9.48 \pm 0.48$ & 4.96 & 52.32 & $-0.29 \pm 0.24$ & $-0.51 \pm 0.47$ \\
\hline \multirow{2}{*}{$\begin{array}{c}\text { Bota } \\
(\mathrm{n}=81)\end{array}$} & Plantation age (YAP) & 3 & 59 & $29.70 \pm 2.01$ & 18.15 & 61.11 & $-0.07 \pm 0.27$ & $-1.55 \pm 0.53$ \\
\hline & FFB Yield $\left(\mathrm{t} \cdot h \mathrm{a}^{-1}\right)$ & 0.29 & 19.97 & $5.54 \pm 0.45$ & 4.05 & 73.10 & $1.18 \pm 0.27$ & $1.27 \pm 0.53$ \\
\hline \multirow{2}{*}{$\begin{array}{l}\text { Mungo } \\
(\mathrm{n}=50)\end{array}$} & Plantation age (YAP) & 4 & 48 & $20.98 \pm 2.22$ & 15.72 & 74.93 & $0.63 \pm 0.34$ & $-1.28 \pm 0.66$ \\
\hline & FFB Yield $\left(\mathrm{t} \cdot h \mathrm{a}^{-1}\right)$ & 0.83 & 16.07 & $6.31 \pm 0.58$ & 4.11 & 65.15 & $0.70 \pm 0.34$ & $-0.43 \pm 0.66$ \\
\hline \multirow{2}{*}{$\begin{array}{l}\text { Idenau } \\
(\mathrm{n}=32)\end{array}$} & Plantation age (YAP) & 3 & 37 & $17.87 \pm 2.05$ & 11.58 & 64.79 & $0.25 \pm 0.41$ & $-1.42 \pm 0.81$ \\
\hline & FFB Yield $\left(\mathrm{t} \cdot h \mathrm{a}^{-1}\right)$ & 2.84 & 16.12 & $8.89 \pm 0.62$ & 3.52 & 39.56 & $0.32 \pm 0.41$ & $-0.79 \pm 0.81$ \\
\hline \multirow{2}{*}{$\begin{array}{l}\text { Illoani-Boa } \\
\quad(\mathrm{n}=28)\end{array}$} & Plantation age (YAP) & 4 & 32 & $15.75 \pm 1.64$ & 8.68 & 55.12 & $-0.06 \pm 0.44$ & $-1.25 \pm 0.86$ \\
\hline & FFB Yield $\left(\mathrm{t} \cdot h \mathrm{a}^{-1}\right)$ & 1.57 & 18.60 & $8.74 \pm 0.87$ & 4.59 & 52.50 & $0.15 \pm 0.44$ & $-0.68 \pm 0.86$ \\
\hline \multirow{2}{*}{$\begin{array}{l}\text { All sites } \\
(\mathrm{n}=318)\end{array}$} & Plantation age (YAP) & 1 & 59 & $19.19 \pm 0.74$ & 14.86 & 77.60 & $0.86 \pm 0.12$ & $-0.55 \pm 0.24$ \\
\hline & FFB Yield $\left(\mathrm{t} \cdot h \mathrm{a}^{-1}\right)$ & 0.00 & 21.20 & $7.70 \pm 0.23$ & 4.58 & 57.19 & $0.38 \pm 0.12$ & $-0.57 \pm 0.24$ \\
\hline
\end{tabular}

Notes: SE, standard error; Std. Dev., standard deviation; CV, coefficient of variation.

Table 3. Correlation between oil palm yield $\left(\mathrm{t} \cdot \mathrm{ha}^{-1}\right)$ and plantation age (YAP).

\begin{tabular}{ccccccc}
\hline Estate & Mondoni & Debundscha & Bota & Mungo & Idenau & Illoani-Boa \\
\hline $\mathrm{N}$ & 106 & 106 & 81 & 50 & 32 & 28 \\
$\mathrm{r}$ & $-0.300^{* *}$ & $0.200^{*}$ & $-0.508^{* *}$ & $-0.494^{* *}$ & $-0.454^{* *}$ & $0.500^{* *}$ \\
\hline
\end{tabular}

Notes : ${ }^{\star *}$, Correlation is significant at the 0.01 level (2-tailed); ${ }^{\star}$ Correlation is significant at the 0.05 level (2-tailed). 

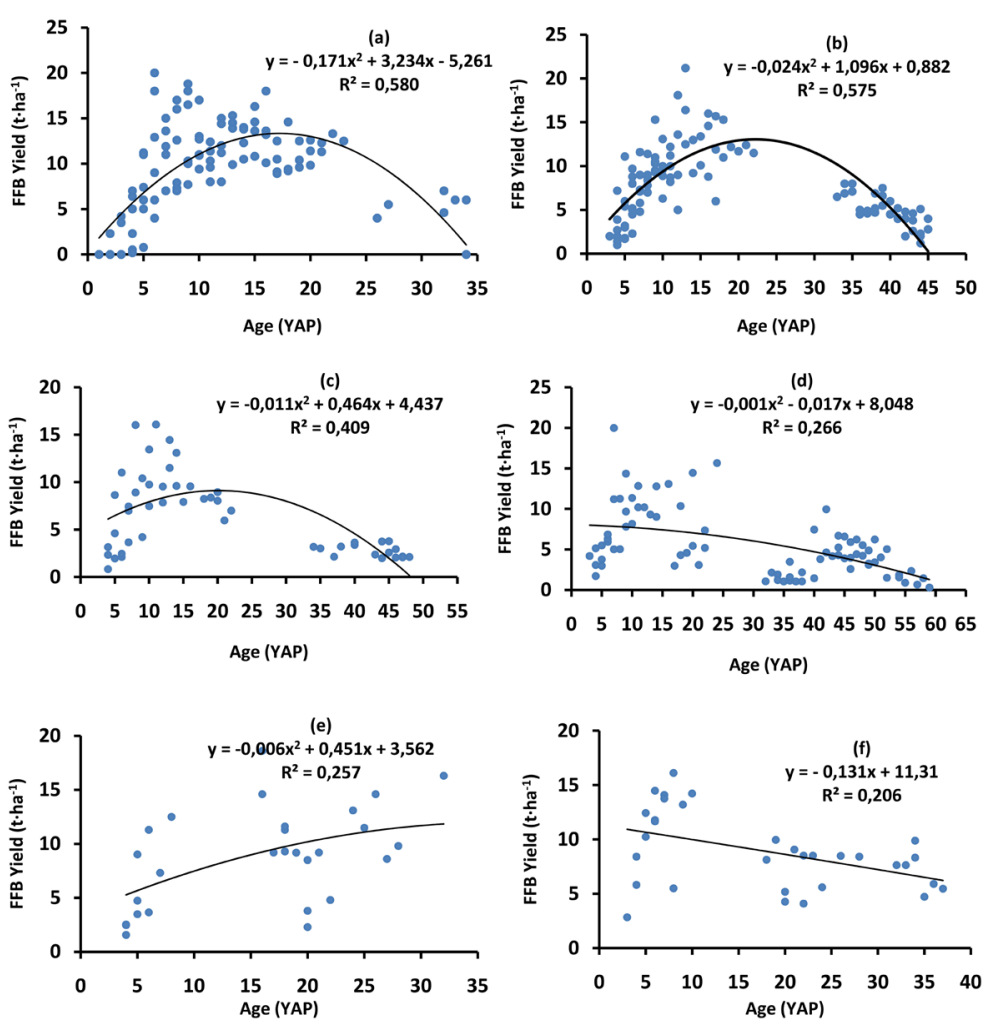

Figure 2. Relationships between FFB yield and plantation age in various estates: (a) Debundscha, (b) Mondoni, (c) Mungo, (d) Bota, (e) Boa-Illoani, (f) Idenau.

The relationships between age and yield (Figure 2) revealed that plantation age could explain between $20.6 \%$ and $58.0 \%$ of the variation in oil palm yield.

Woittiez et al. [32] investigated the influence of plantation age (measured in YAP), location (contrasting soil types) and tissue nutrient concentrations in leaf $(\mathrm{N}, \mathrm{P}, \mathrm{K}, \mathrm{Mg}$, and $\mathrm{Ca})$ on vegetative growth and oil palm yield. In their results, a full model explained $64 \%$ of the variation in vegetative growth meanwhile $56 \%$ of the variation was explained by location and palm age only, with palm age having a significant negative effect on yield.

As concerns yields in different age classes, it was observed that young plantations (3 - 8 YAP) produced average oil palm yields of $6.91 \mathrm{t} \cdot \mathrm{ha}^{-1}$, prime $(9-18$ YAP) produced an average of $11.52 \mathrm{t} \cdot \mathrm{ha}^{-1}$, ageing (19 - $\left.23 \mathrm{YAP}\right)$ produced an average yield of $8.67 \mathrm{t} \cdot \mathrm{ha}^{-1}$ and the old plantations ( $>23 \mathrm{YAP}$ ) produced on average $4.66 \mathrm{t} \cdot \mathrm{ha}^{-1}$ (Figure $3 \&$ Table 4).

These results are in concordance with the observations reported by Euler et al. [33]. However, the yields in various classes are very low compared to the potential yields. In all sites, actual yields are far smaller than the minimum potential yield of 12 tha ${ }^{-1}$.

\subsection{Estimated Yield Gaps in Oil Palm}

The average yield gap for different estates is shown in Table 5, while the yield gaps in the different age classes are shown in Table 6. In general, yields in all es- 
tates were declared low $\left(<12 \mathrm{t} \cdot \mathrm{ha}^{-1}\right)$. Debundscha estate had the lowest yield gap (37.9\%), followed by Idenau (35.6\%) and Mondoni (30.4\%). As concerns yield

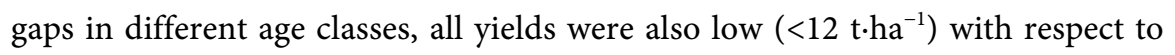
the potential yields. The prime age class ( $9-18$ years) had the lowest yield gap of $46.08 \%$. In the central region of Columbia, Ruiz et al. (2017) observed that 50\% of prime plantations (6 - 10 years) had high yields $\left(>33 \mathrm{t} \cdot \mathrm{ha}^{-1}\right), 43 \%$ had intermediate yields $\left(21-33 \mathrm{t} \cdot \mathrm{ha}^{-1}\right)$ and only $7 \%$ had low yields $\left(<21 \mathrm{t} \cdot \mathrm{ha}^{-1}\right)$. As concerns ageing plantations, Ruiz et al. [15] reported that more than $50 \%$ of ageing plantations ( $>16$ years) had high yields $\left(>33 \mathrm{t} \cdot \mathrm{ha}^{-1}\right)$.

\subsection{Influence of Soil Parent Material on Oil Palm Yield}

The relationship between oil palm yield and plantation age grouped under volcanic and sedimentary parent materials is shown in Figure 4. Mean yields in the two areas were significantly different at the $95 \%$ confidence interval $(t=3.704$, $\mathrm{p}<0.05)$. The average yield on volcanic parent materials is $7.94 \pm 0.32 \mathrm{t} \cdot \mathrm{ha}^{-1}$ ( standard deviation $=4.79 \mathrm{t} \cdot \mathrm{ha}^{-1}$ ), while the average yield in plantations located on sedimentary parent materials is $7.43 \pm 0.32 \mathrm{t}^{-\mathrm{ha}^{-1}}$ (standard deviation $=4.30$ $\mathrm{t} \cdot \mathrm{ha}^{-1}$ ). In both sites, there was a significant negative correlation between plantation age and yield at the $99 \%$ confidence interval $\left(r=-0.379^{\star *}\right.$ for plantations on volcanic parent material and $\mathrm{r}=-0.287^{\star \star}$ for plantations on sedimentary parent material), indicating that yields decrease with increase in plantation age. In plantations located on sedimentary parent materials, plantation age explained more than $40 \%$ in the yield variation, compared to about $24 \%$ in sites with volcanic parent materials, following a quadratic model. Coefficient of variation was very high for yields obtained in both sites $(>50 \%)$.

Table 4. Descriptive statistics of oil palm yield $\left(\mathrm{t} \cdot \mathrm{ha}^{-1}\right)$ for different age classes in all sites.

\begin{tabular}{cccccccc}
\hline Age class & Minimum & Maximum & Mean \pm SE & Std. Dev. & CV $(\%)$ & Skewness \pm SE & Kurtosis \pm SE \\
\hline Young $(3-8$ years $)(\mathrm{n}=124)$ & 0.00 & 20.00 & $6.91 \pm 0.41$ & 4,51 & 65,27 & $0.73 \pm 0.21$ & $0.12 \pm 0.43$ \\
Prime $(9-18$ years $)(\mathrm{n}=119)$ & 3.00 & 21.20 & $11.52 \pm 0.29$ & 3,25 & 28,21 & $0.26 \pm 0.22$ & $0.26 \pm 0.44$ \\
Ageing $(19-23$ years $)(\mathrm{n}=38)$ & 2.30 & 14.45 & $8.67 \pm 0.53$ & 3,26 & 37.60 & $-0.24 \pm 0.38$ & $-1.01 \pm 0.75$ \\
Old $(>23$ years $)(\mathrm{n}=117)$ & 0.00 & 16.30 & $4.66 \pm 0.28$ & 3,05 & 65.45 & $1.42 \pm 0.22$ & $2.93 \pm 0.44$ \\
\hline
\end{tabular}

Table 5. Average yield gap (\%) and yield rating in different oil palm estates.

\begin{tabular}{ccccccc}
\hline Estate & Mondoni & Debundscha & Bota & Mungo & Idenau & Illoani-Boa \\
\hline Yield gap (\%) & 30.4 & 37.9 & 22.2 & 25.2 & 35.6 & 18.36 \\
Rating & Low & Low & Low & Low & Low & Low \\
\hline
\end{tabular}

Table 6. Average yield gap (\%) and yield rating in different age classes.

\begin{tabular}{ccccc}
\hline Age class & Young $(3-8$ YAP $)$ & Prime $(9-18$ YAP $)$ & Ageing $(19-23$ YAP $)$ & Old $(>23$ YAP $)$ \\
\hline Yield gap $(\%)$ & 26.76 & 46.08 & 34.68 & 18.64 \\
Rating & Low & Low & Low & Low \\
\hline
\end{tabular}



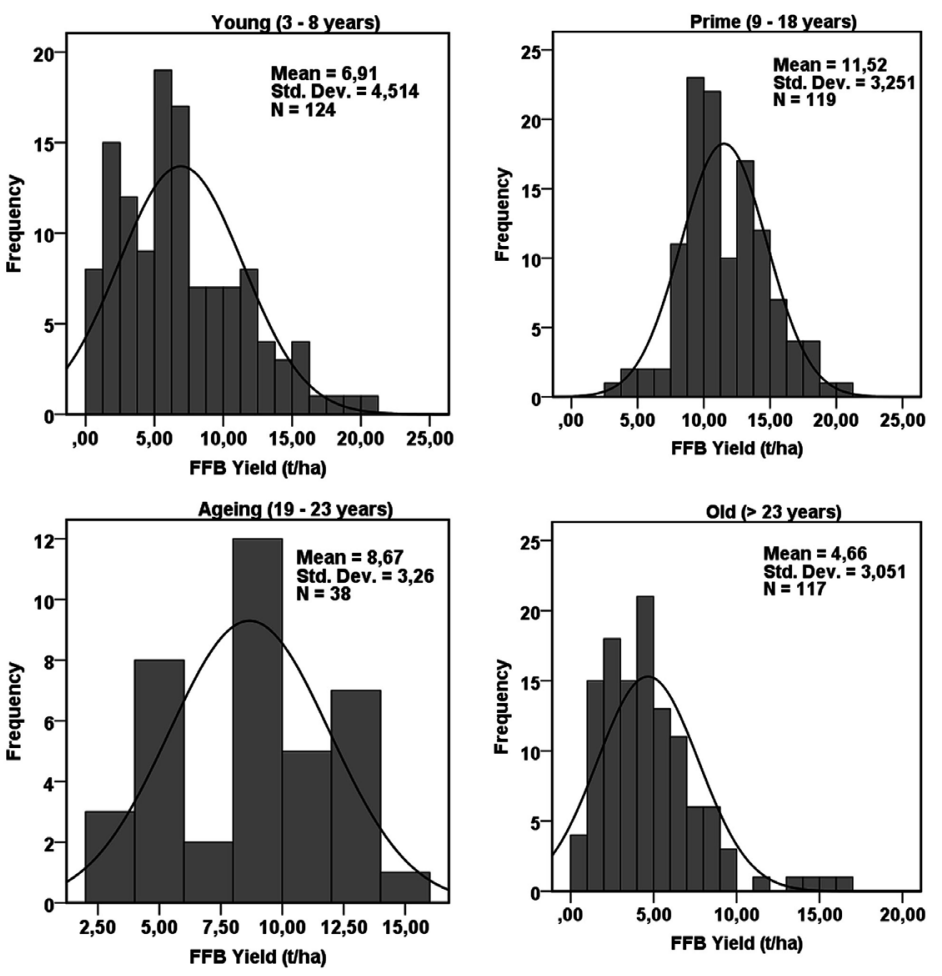

Figure 3. Variation in oil palm yield across different age classes in the study area.
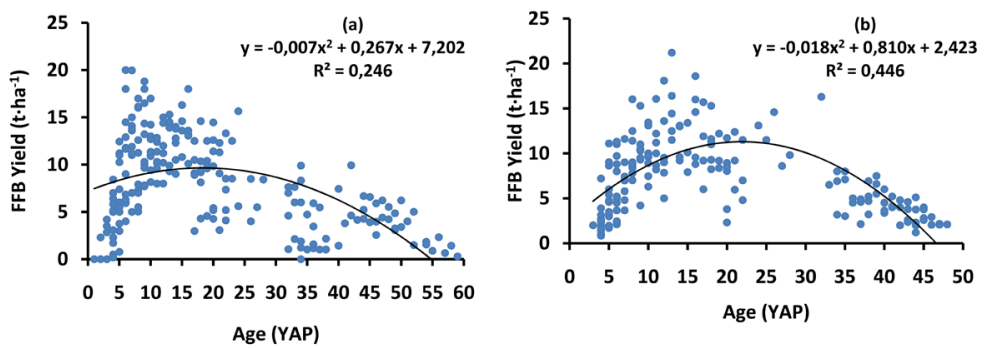

Figure 4. Relationship between plantation age and oil palm yield on different soil parent materials. (a) Plantations on volcanic parent materials, (b) Plantations on sedimentary parent materials.

As concerns mean yields obtained in different age classes from the two locations, it was observed that except for old plantations, all age classes (from young to ageing) had higher yields in plantations located on volcanic parent materials compared to those on sedimentary parent materials. The difference in mean yields was however significant at the $95 \%$ confidence interval only in the young phase $(t=3.724, p=0.000)$. The prime phases in both areas had medium coefficients of variation (between 15\% and 35\%), indicating that yields are more stable during this phase of oil palm growth compared to other phases. In general, the coefficient of variation was high $(>35 \%)$ in all phases of plantations established on volcanic and sedimentary parent materials. Normality plots of FFB yield in the various age classes showed that the data was not normally distributed in the young and old phases (Figure 5 and Figure 6). The median yields in all age 
classes were higher in plantations located on volcanic parent materials compared to those on sedimentary parent materials (Table 7).
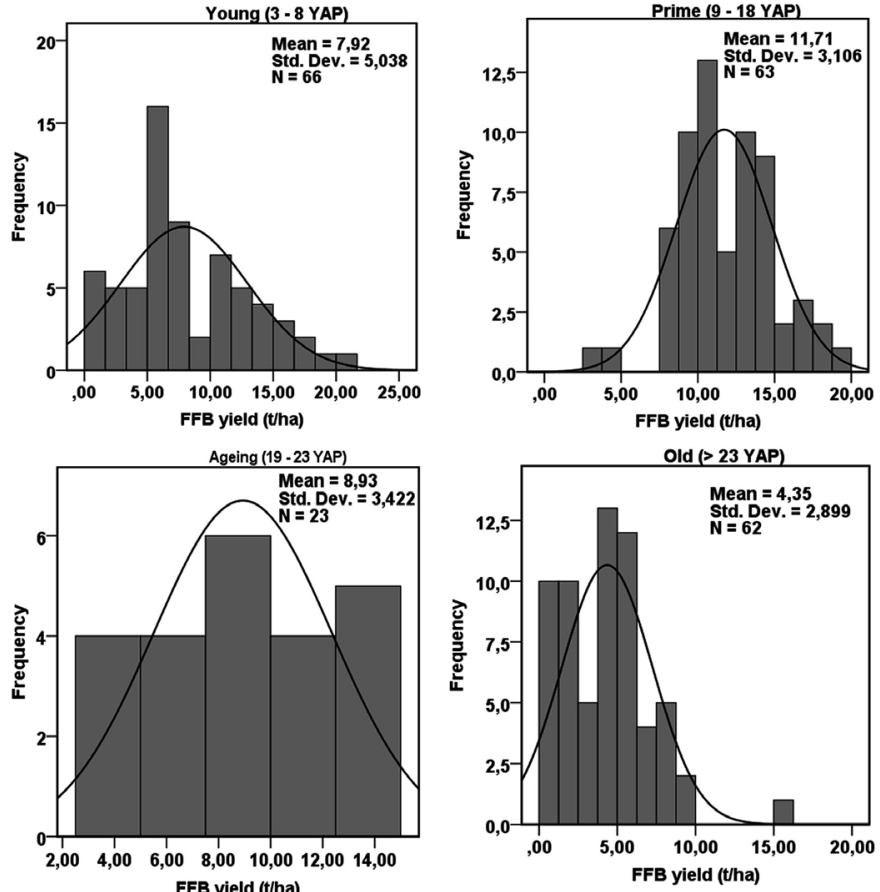

Figure 5. Variation in oil palm yield across different age classes in plantations located on volcanic parent materials.
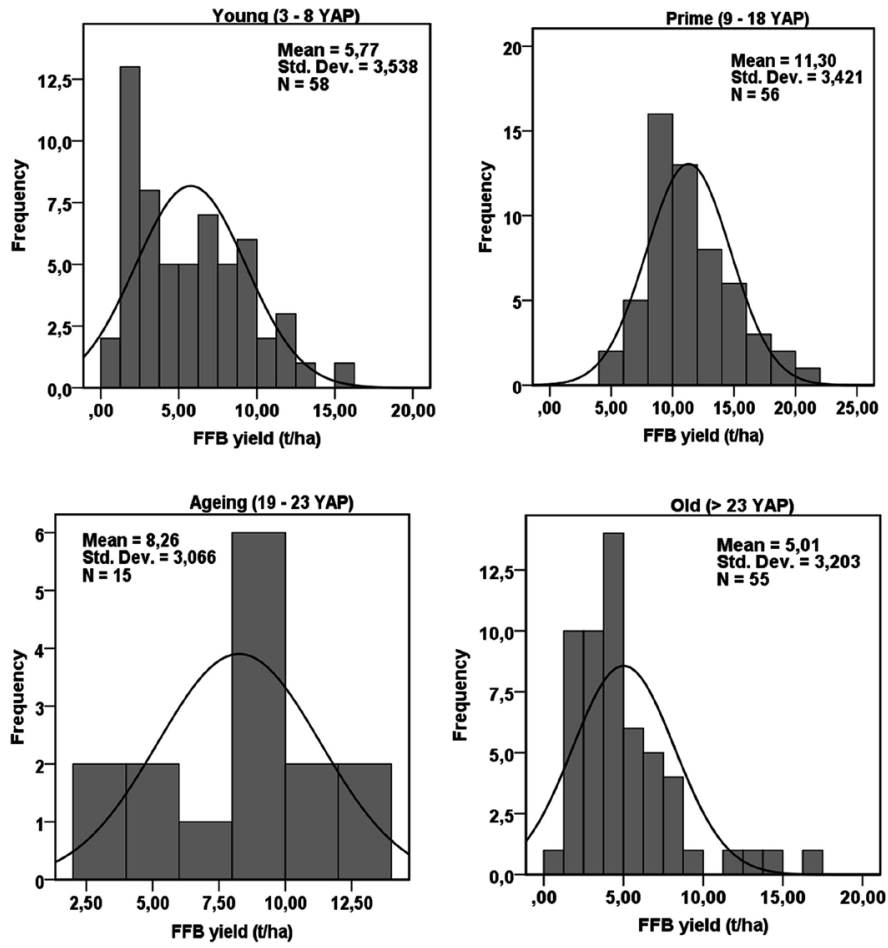

Figure 6. Variation in oil palm yield across different age classes in plantations located on sedimentary parent materials. 
Table 7. Descriptive statistics of oil palm yield $\left(\mathrm{t} \cdot \mathrm{FFB} \cdot \mathrm{ha}^{-1}\right)$ in different age classes for plantations in different locations.

\begin{tabular}{|c|c|c|c|c|c|c|c|c|}
\hline & \multicolumn{4}{|c|}{ Plantations on volcanic ash parent materials } & \multicolumn{4}{|c|}{ Plantations on sedimentary parent materials } \\
\hline & Young & Prime & Ageing & Old & Young & Prime & Ageing & Old \\
\hline Mean \pm SE & $7.92 \pm 0.62$ & $11.71 \pm 0.39$ & $8.93 \pm 0.71$ & $4.35 \pm 0.37$ & $5.77 \pm 0.46$ & $11.29 \pm 0.46$ & $8.26 \pm 0.79$ & $5.01 \pm 0.43$ \\
\hline Median & 6.92 & 11.35 & 9.60 & 4.19 & 5.10 & 10.45 & 8.50 & 4.10 \\
\hline Std. Dev. & 5.04 & 3.11 & 3.42 & 2.89 & 3.54 & 3.42 & 3.07 & 3.20 \\
\hline $\mathrm{CV}(\%)$ & 63.62 & 26.52 & 38.32 & 66.64 & 61.37 & 30.29 & 37.13 & 63.90 \\
\hline Minimum & 0.00 & 2.98 & 3.07 & 0.00 & 0.83 & 4.21 & 2.30 & 1.20 \\
\hline Maximum & 20.00 & 18.80 & 14.45 & 15.65 & 16.02 & 21.20 & 12.40 & 16.30 \\
\hline Skewness \pm SE & $0.53 \pm 0.29$ & $-0.05 \pm 0.30$ & $-0.23 \pm 0.48$ & $1.06 \pm 0.30$ & $0.59 \pm 0.31$ & $0.56 \pm 0.32$ & $-0.42 \pm 0.58$ & $1.74 \pm 0.32$ \\
\hline Kurtosis \pm SE & $-0.36 \pm 0.58$ & $0.39 \pm 0.59$ & $-1.23 \pm 0.94$ & $2.39 \pm 0.59$ & $-0.29 \pm 0.62$ & $0.39 \pm 0.63$ & $-0.52 \pm 1.12$ & $3.27 \pm 0.63$ \\
\hline
\end{tabular}

Notes: SE, standard error; Std. Dev., standard deviation; CV, coefficient of variation.

\section{Discussion}

\subsection{Influence of Plantation Age and Soil Parent Material on Oil Palm Yield}

The high yield gaps observed in oil palm plantations of Cameroon are due to a combination of different factors such as inappropriate soil fertility management, the impact of pests and diseases, and other factors among which plantation age contributes from $20 \%$ to $50 \%$ in yield variation. In Andhra Pradesh (India), Latha et al. [34] observed that $50 \%$ of 5 years old plantations produced $10-15$ $\mathrm{t} \cdot \mathrm{ha}^{-1}$ of FFB, while $78 \%$ of 9 years old plantation produced more than $20 \mathrm{t} \cdot \mathrm{ha}^{-1}$ and in 24 years old plantation, $66 \%$ of palms recorded more than $30 \mathrm{t} \cdot \mathrm{ha}^{-1}$ of FFB. The low yields and large yield gaps observed in southwest Cameroon compared to other parts of the world such as Malaysia and Indonesia is a clear indication that oil palm production needs to be intensified in order to produce acceptable yields. The first measure to intensify oil palm production and limit deforestation should be the replacement of old palms. From Figure 2 and Figure 3 , it is suggested that, based on yields observed at various ages, the oil palm replanting age should be 23 YAP. With respect to the influence of plantation age on oil palm yield (over a 25-year period), a comparison of our results with those from other studies (as reviewed by [17]) indicates that mean actual yields in southwest Cameroon are about 2 - 3 times lower than actual yields elsewhere and about 4 times lower than nutrient/water limited yields and potential yields.

The plantations located on volcanic parent materials have more fertile young volcanic ash (mineral) soils which are richer in plant nutrients, compared to those with highly weathered soils found on old coastal sediments, this as a result of the presence of more weatherable primary minerals present in young volcanic soils. In general, soil minerals influence soil fertility and crop growth by controlling the release and supply of nutrients and by influencing soil physical properties. 
Soil physical properties (such as texture, structure, drainage, porosity, effective soil depth) and chemical properties (such as soil $\mathrm{pH}, \mathrm{C}$ content, $\mathrm{N}$ content, $\mathrm{P}$ content, CEC, base saturation and exchangeable bases) as influenced by parent material, have a direct influence on plantation management and yield [35]. Woittiez et al. [17] also reported that oil palm growth and yield greatly depends on the potential of the soil parent material. Apart from the influence of soil type on yield, the areas with volcanic parent materials also witness a well distributed rainfall pattern throughout the year with mean annual rainfall exceeding 8000 $\mathrm{mm}$. It is therefore evident that in addition to plantation age, soils developed from volcanic parent materials, alongside high amounts of rainfall favour oil palm yields. According to [17], soil type (parent material) and rainfall are major contributing factors to the water-limited yield in oil palm. Although we did not measure the soil water holding capacity of the soils, it appears that the plantations located on sedimentary parent materials (mostly alluvial sediments) suffer from impeded drainage due to high water table at some periods of the year (field observation), especially in the Boa plain (Illoani-Boa estates). Henson et al. [36] observed that impeded drainage as caused by high water tables can significantly reduce oil palm yields $(20 \%-30 \%$ yield loss) by affecting net photosynthesis, stomata conductance and transpiration. Lee and Ong [37] observed that water logging in low-lying areas can cause the death of up to $75 \%$ of immature palms.

The lateral movement of soil water as influenced by a high water table can also influence plant nutrient availability. On the other hand, the plantations located on volcanic parent materials have soils with good drainage, which favours the growth of palms. Based on the type of parent material, specific measures such as water drainage can be used to improve on the soil condition so as to favour oil palm growth and productivity. According to Chuah and Lim [38], drainage of frequently flooded plantations can increase fresh fruit yield by $>5 \mathrm{t} \cdot \mathrm{ha}^{-1}$.

\subsection{Closing Yield Gaps through Oil Palm Replanting}

Estimated yield recovery through oil palm replanting (assuming similar management type) is shown in Table 8. With the exception of plantations in Illoani-Boa, results indicate that replanting of oil palm trees after 23 years of exploitation is beneficial in terms of yield output. Estimated mean yields obtained if old oil palms were replanted can increase by $43 \%$ - 65\% compared to the current yields obtained from the old plantations. In Bota, Mungo and Idenau, the yield difference is significant $(\mathrm{p}<0.05)$. Although the yield difference is insignificant in Mondoni and Debundscha, yields can be increased by $46.28 \%$ and $43.08 \%$, respectively, if old palms are replanted. Jalani et al. [39] reported that one of the immediate strategies to increase oil palm yields in Malaysia is through the identification of the optimal age profile and then the establishment and practice of a replanting program. With yield gaps ranging between 1.0 and $2.4 \mathrm{t} \cdot \mathrm{ha}^{-1} \cdot \mathrm{yr}^{-1}$ of palm oil observed in Malaysia, one of the best measures adopted to close the yield gaps has been the replanting of more than 200,000 ha of palms exceeding 
Table 8. Comparison of yields obtained from old plantations and those estimated if replanted on time (23 YAP).

\begin{tabular}{|c|c|c|c|c|c|c|}
\hline Estate & Mondoni & Debundscha & Bota & Mungo & Idenau & Illoan-Boa \\
\hline Age of oldest plantations as of 2017 & 45 & 34 & 59 & 48 & 37 & 32 \\
\hline $\begin{array}{l}\text { No. of years in excess of optimal } \\
\text { replanting age (23 YAP) }\end{array}$ & 22 & 11 & 36 & 25 & 14 & 9 \\
\hline $\begin{array}{l}\text { Mean yields obtained in plantations } \\
\text { with age }>23 \text { YAP }\left(\mathrm{t} \cdot \mathrm{FFB} \cdot \mathrm{ha}^{-1}\right)\end{array}$ & 4.77 & 4.73 & 3.66 & 2.77 & 7.21 & 12.31 \\
\hline $\begin{array}{l}\text { Estimated mean yield increase if } \\
\text { trees were replanted } 23 \mathrm{YAP}\left(\mathrm{t} \cdot \mathrm{ha}^{-1}\right)\end{array}$ & 8.88 & 8.31 & 7.93 & 7.98 & 11.04 & 5.86 \\
\hline $\mathrm{t}$ value & 1.165 & -2.425 & 4.919 & 2.965 & 2.375 & -4.020 \\
\hline probability & 0.253 & 0.051 & $0.000^{*}$ & $0.010^{*}$ & $0.042^{*}$ & $0.010^{*}$ \\
\hline Yield increase through replanting (\%) & 46.28 & 43.08 & 53.85 & 65.29 & 34.69 & -52.40 \\
\hline
\end{tabular}

Notes: ${ }^{*}$ Mean values are significantly different at $\mathrm{p}<0.05$.

25 years old using new planting materials [39]. Additionally, replanting, as a means of increasing oil palm yields, appears to be a prioritized management technique in Malaysia given that oil palm expansion from suitable to marginal lands (such as hills and peatlands) is highly discouraged. Still in Malaysia, it has been estimated that yields can be increased by about $45 \%$ if oil palm cultivation can be done exclusively on suitable lands with old oil palms ( $>25$ years) replanted such that $15 \%$ of the land is covered with the immature phase ( $<3$ YAP) at any one time [40]. Recently in Indonesia, the government has launched huge replanting programs as a measure for intensifying oil palm yield while conserving the environment. Afriyanti et al. [41] reported that although oil palm replanting with good planting materials is a sure means of reaching potential yields (27 - $38 \mathrm{t} \cdot \mathrm{FFB} \cdot \mathrm{ha}^{-1}$ ) in Indonesia, this may not be the case with smallholders due to the very high costs required for replanting, which they cannot afford. Notwithstanding, replanting proves to be an effective means of increasing oil palm yields without necessarily increasing the cultivation area.

\section{Conclusion}

This study investigated the quantitative relationship between oil palm age and yield, and the influence of location (parent material) on oil palm yield. The results indicated that oil palm age has a significant effect on yield and accounts for at least $20 \%$ in the variation of yield. Additionally, there was also a significant difference in oil palm yields within the different locations, with the highest yields obtained on volcanic parent materials. The very low yields $\left(<12 \mathrm{t} \cdot \mathrm{FFB} \cdot \mathrm{ha}^{-1}\right)$ and the large yield gaps observed necessitate urgent measures for plantation intensification in order to increase yields and sustain production. One of the urgent measures needed to increase yields while conserving the environment, is the replanting of aged plantations ( $\geq 23$ YAP), while considering other management techniques such as appropriate fertilization, management of pests and diseases, soil water management, etc. Further studies are needed to investigate the com- 
bined influence of other factors (such as soil nutrient status) alongside oil palm age, on oil palm yield. Additionally, studies are necessary to capture the scenario in smallholder plantations, given that smallholders constitute a very important component of the oil palm industry in Cameroon. Further studies are also required to investigate the economic implications (in monetary terms) of the recommended optimal replanting age.

\section{Acknowledgements}

We express our sincere thanks to the administration of the Cameroon Development Corporation (CDC) for granting us permission to carry out this research in their plantations. We are particularly grateful to all estate managers for granting us access to various data sources and also for their invaluable discussions and comments during field work.

\section{Conflicts of Interest}

The authors declare no conflicts of interest regarding the publication of this paper.

\section{References}

[1] Comte, I., Colin, F., Whalen, J.K., Grünberger, O. and Caliman, J.P. (2012) Agricultural Practices in Oil Palm Plantations and Their Impact on Hydrological Changes, Nutrient Fluxes and Water Quality in Indonesia: A Review. Advances in Agronomy, 116, 71-124. https://doi.org/10.1016/B978-0-12-394277-7.00003-8

[2] Butler, R.A., Koh, L.P. and Ghazoul, J. (2009) REDD in the Red: Palm Oil Could Undermine Carbon Payment Schemes. Conservation Letters, 2, 67-73. https://doi.org/10.1111/j.1755-263X.2009.00047.x

[3] FAO (2014) FAOSTAT Gateway. http://faostat3.fao.org/home/E

[4] Savilaakso, S., Garcia, C., Garcia-Ulloa, J., Ghazoul, J., Groom, M., Guariguata, M.R., Laumonier, Y., Nasi, R., Petrokofsky, G., Snaddon, J. and Zrust, M. (2014) Systematic Review of Effects on Biodiversity from Oil Palm Production. Environmental Evidence, 3, 4. https://doi.org/10.1186/2047-2382-3-4

[5] Vijay, V., Pimm, S.L., Jenkins, C.N. and Smith, S.J. (2016) The Impacts of Oil Palm on Recent Deforestation and Biodiversity Loss. PLOS ONE, 11, e0159668. https://doi.org/10.1371/journal.pone.0159668

[6] Bessou, C., Chase, L.D.C., Henson, I.E., Abdul-Manan, A.F.N., Milài Canals, L., Agus, F., Sharma, M. and Chin, M. (2014) Pilot Application of PalmGHG, the Roundtable on Sustainable Palm Oil Greenhouse Gas Calculator for Oil Palm Products. Journal of Cleaner Production, 73, 136-145. https://doi.org/10.1016/j.jclepro.2013.12.008

[7] Dislich, C., Keyel, A.C., Salecker, J., Kisel, Y., Meyer, K.M., Auliya, M., Barnes, A.D., Corre, M.D., Darras, K., Faust, H., et al. (2017) A Review of the Ecosystem Functions in Oil Palm Plantations, Using Forests as a Reference System. Biological Reviews, 92, 1539-1569. https://doi.org/10.1111/brv.12295

[8] Pirker, J., Mosnier, A., Kraxner, F., Havlík, P. and Obersteiner, M. (2016) What Are the Limits to Oil Palm Expansion? Global Environmental Change, 40, 73-81. https://doi.org/10.1016/j.gloenvcha.2016.06.007 
[9] Corley, R.H.V. (2009) How Much Palm Oil Do We Need? Environmental Science and Policy, 12, 134-139. https://doi.org/10.1016/j.envsci.2008.10.011

[10] Fairhurst, T.H. and Mutert E. 1999. Interpretation and Management of Oil Palm Leaf Analysis Data. Better Crops International, 13, 48-51.

[11] Nkongho, R.N., Feintrenie, L. and Levang, P. (2014) Strengths and Weaknesses of the Smallholder Oil Palm Sector in Cameroon. OCL, 21.

[12] Feintrenie, L. (2012) Oil Palm in Cameroon: Risks and Opportunities. Nature et Faune, 26, 23-27

[13] Pingpoh, D.P. and Senahoun, J. (2008) Extent and Impact of Vegetable Oils Import Surges in Cameroon. 12th EAAE Congress on People, Food and Environments: Global Trends and European Strategies, Gent, Belgium, 26-29 August 2008.

[14] FAOSTAT (2017) Crops Data. Food and Agriculture Organization of the United Nations. http://faostat3.fao.org

[15] Ruiz, A., Mesa, F., Mosquera, M., Barrientos, F. and Carlos, J. (2017) Technological Factors Associated with Oil Palm Yield Gaps in the Central Region in Colombia. Agronomia Colombiana, 35, 256-264.

[16] Fischer, R. (2015) Definitions and Determination of Crop Yield, Yield Gaps and of Rates of Change. Field Crops Research, 182, 9-18.

https://doi.org/10.1016/j.fcr.2014.12.006

[17] Woittiez, L.S., van Wijk, M.T., Slingerland, M., van Noordwijk, M. and Giller, K.E. (2017) Yield Gaps in Oil Palm: A Quantitative Review of Contributing Factors. European Journal of Agronomy, 83, 57-77. https://doi.org/10.1016/j.eja.2016.11.002

[18] Tabi, F.O. and Muki, E. (2009) Agro-Economic Implications of Weather Variation on Oil Palm Yield and Yield Components in the Humid Forest Zone of Cameroon. IOP Conference Series. Earth and Environmental Sciences, 6, Article ID: 472015. https://doi.org/10.1088/1755-1307/6/47/472015

[19] Kimengsi, J.N. and Muluh, N.G. (2013) A Comparative Assessment of the Effect of Climatic Variations on the Crops of the Cameroon Development Corporation (CDC): Adaptation Options. Environmental and Natural Resources Research, 3, 144-156. https://doi.org/10.5539/enrr.v3n1p144

[20] Nkodo, F. and Ambang, Z. (2015) Simple and Multiple Linear Regressions between Oil Palm Annual Yields and Yearly Climatic Variables over a 23-Year-Period (1990-2012) in the Coastal Zone of Cameroon. International Journal of Biological and Chemical Sciences, 9, 2833-2846. https://doi.org/10.4314/ijbcs.v9i6.24

[21] Sokoudjou, H. (2001) The Bitter Fruit of Oil Palm: Dispossession and Deforestation-The Case of Cameroon: Oil Palm Plantations, Yet Another Threat to Cameroon's Native Forests? World Rainforest Movement, 74.

[22] Fairhurst, T. and Griffiths, W. (2014) Oil Palm: Best Management Practices for Yield Intensification. International Plant Nutrition Institute (IPNI), Singapore.

[23] Bessou, C., Verwilghen, A., Beaudoin-Ollivier, L., Marichal, R., Ollivier, J., Baron, V., Bonneau, X., Carron, M.P., Snoeck, D., Naim, M., et al. (2017) Agroecological Practices in Oil Palm Plantations: Examples from the Field. $O C L, 24$.

[24] Zulkifli, H., Halimah, M., Chan, K.W., Choo, Y.M. and Mohd Basri, W. (2010) Life Cycle Assessment for Oil Palm Fresh Fruit Bunch Production from Continued Land Use for Oil Palm Planted on Mineral Soil (Part 2). Journal of Oil Palm Research, 22, 887-894.

[25] Ling, A.H. (2012) Weather Effects on Palm Oil Production: Supply Outlook 2012/2013. Paper Presented at the Palm Oil Trade Fair and Seminar (POTS) 2012, 
MPOC, Malaysia.

[26] Faris, J.E. (1960) Analytical Techniques Used in Determining the Optimum Replacement Pattern. Journal of Farm Economics, 42, 755-766. https://doi.org/10.2307/1235110

[27] Pirker, J. (2015) Mapping Oil Palm Suitability Protocol. Technical Annex 1. Oil Palm Suitability Map for South West Cameroon. IEL International, Hong Kong, 23.

[28] Pirker, J. and Mosnier, A. (2015) Global Oil Palm Suitability Assessment. IIASA Interim Report, 27.

[29] Fraser, P., Hall, J.B. and Healey, J.R. (1998) Climate of the Mount Cameroon Region. University of Wales, Bangor, SENR Publication No. 16, 56.

[30] Yerima, B.P.K. and Van Ranst, E. (2005) Major Soil Classification Systems Used in the Tropics: Soils of Cameroon. Trafford Publishing, Canada.

[31] Feintrenie, L., Gazull, L., Goulaouic, R. and Miaro, L. (2016) Spatialized Production Models for Sustainable Palm Oil in Central Africa: Choices and Potentials. 17.

[32] Woittiez, L.S., Turhina, S., Deccy, D., Slingerland, M., van Noordwijk, M. and Giller, K.E. (2019) Fertiliser Application Practices and Nutrient Deficiencies in Smallholder Oil Palm Plantations in Indonesia. Experimental Agriculture, 55, 543-559. https://doi.org/10.1017/S0014479718000182

[33] Euler, M., Hoffmann, M.P., Fathoni, Z. and Schwarze, S. (2016) Exploring Yield Gaps in Smallholder Oil Palm Production Systems in Eastern Sumatra, Indonesia. Agricultural Systems, 146, 111-119. https://doi.org/10.1016/j.agsy.2016.04.007

[34] Latha, P.M., Kalpana, M. and Manorama, K. (2016) Influence of Plantation Age on Production Performance of Oil Palm in Andhra Pradesh. The Journal of Research ANGRAU, 44, 98-103.

[35] Paramananthan, S. (2013) Soil Properties and Their Influence on Oil Palm Management and Yield. In: Webb, M.J., Nelson, P.N., Bessou, C., Caliman, J.P. and Sutarta, E.S., Eds., Sustainable Management of Soil in Oil Palm Plantings, ACIAR Proceedings No. 144, Australian Centre for International Agricultural Research, Canberra, 70.

[36] Henson, I.E., Harun, M.H. and Chang, K.C. (2008) Some Observations on the Effects of High Water Tables and Flooding on Oil Palm and a Preliminary Model of Oil Palm Water Balance and Use in the Presence of a High Water Table. Oil Palm Bulletin, 56, 14-22.

[37] Lee, W.K. and Ong, B.K. (2006) The Unseen Flood: Water Logging in Large Oil Palm Plantations. Jurutera, 28-31.

[38] Chuah, J.H. and Lim, K.H. (1992) Water Management and Irrigation of Oil Palm on Coastal Soils-Sime Darby's Experience. Planter, 65, 334-344

[39] Jalani, B.S., Basiron, Y., Darus, A., Chan, K.W. and Rajanaidu, N. (2002) Prospects of Elevating National Oil Palm Productivity: A Malaysian Perspective. Oil Palm Industry Economy Journal, 2, 1-9.

[40] Ming, K.K. and Chandramohan, D. (2002) Malaysian Palm Oil Industry at Crossroads and Its Future Direction. Oil Palm Industry Economy Journal, 2, 10-15.

[41] Afriyanti, D., Kroeze, C. and Saad, A. (2016) Indonesia Palm Oil Production without Deforestation and Peat Conversion by 2050. Science of the Total Environment, 557, 562-570. https://doi.org/10.1016/j.scitotenv.2016.03.032 